\title{
Apakah Keberadaan Komisaris Keluarga dan Komisaris Independen Meningkatkan Pengungkapan Risiko?
}

\author{
Doddy Setiawan ${ }^{1}$ \\ Elisa Apriliani Andriyanto ${ }^{2}$ \\ ${ }^{1,2}$ Fakultas Ekonomi dan Bisnis, Universitas Sebelas Maret, Indonesia \\ email:doddy.setiawan@staff.uns.ac.id
}

DOI: https://doi.org/10.24843/JIAB.2019.v14.i01.p01

\begin{abstract}
ABSTRAK
Jurnal Ilmiah Akuntansi dan Bisnis (JIAB)

https://ojs.unud.ac.id/index.php/jiab/ user/profile

Volume 14

Nomor 1

Januari 2019

Halaman 01-09

p-ISSN 2302-514X

e-ISSN $\underline{2303-1018}$

\section{INFORMASI ARTIKEL}

Tanggal masuk: 02 Oktober 2018

Tanggal revisi:

25 November 2018

Tanggal diterima:

12 Desember 2018

Penelitian ini bertujuan menguji keberadaan komisaris keluarga dan komisaris independen terhadap pengungkapan risiko. Penelitian menggunakan sampel perusahaan di Indonesia yang melakukan penawaran saham perdana atau initially public offering (IPO). Penelitian menggunakan uji regresi berganda untuk menguji dampak komisaris keluarga dan komisaris independen terhadap pengungkapan risiko. Sampel penelitian ini terdiri dari 204 perusahaan nonkeuangan yang melakukan penawaran saham perdana pada periode 2001-2017. Hasil penelitian menunjukkan komisaris keluarga dan komisaris independen berpengaruh positif terhadap pengungkapan risiko. Hal ini menunjukkan pentingnya perusahaan untuk meningkatkan jumlah komisaris independen dan mempertahankan keberadaan komisaris keluarga pada saat IPO

Kata kunci: Komisaris keluarga, komisaris independen, penawaran saham perdana,dewan komisaris

\section{Do Family Commissioners and Independent Commissioners Affect Risk Disclosure?}

ABSTRACT

This research aims to examine the effect of family commissioners and independent commissioners on risk disclosure using Indonesian firms that engaged in initial public offering (IPO). This research uses multiple regression analysis to test the effect of family commissioners and independent commissioners on risk disclosure. The study sample consists of 204 nonfinancial firms that engaged in IPO during the period of 2001-2017. The result of the study shows that family commissioners and independent commissioners have positively affected risk disclosure. Therefore, it is important for companies to add more independent commissioners and maintain family commissioners during IPO.
\end{abstract}

Keywords: Family commissioners, independent commissioners, initial public offering, board of commissioner

\section{PENDAHULUAN}

Perusahaan di Indonesia sebagian besar dimiliki oleh keluarga (Carney \& Child, 2013; Setiawan, Bandi, Phua, \& Trinugroho, 2016). Pihak keluarga sebagai pemilik mayoritas bisa memasukkan anggota keluarga sebagai bagian dari dewan komisaris dan dewan direksi. Anggota keluarga yang berada di dewan komisaris ini disebut dengan komisaris keluarga dan berfungsi untuk menjaga kepentingan keluarga di dalam perusahaan tersebut.

Salah satu peristiwa penting dalam siklus hidup perusahaan adalah saat perusahaan memutuskan untuk menawarkan sahamnya ke publik. Saat ini adalah saat perusahaan berusaha untuk memperoleh 
tambahan pendanaan dari masyarakat. Akan tetapi, terdapat asimetri informasi antara perusahaan dan calon investor. Salah satu cara untuk meminimalkan asimetri informasi adalah dengan memberikan sinyal kepada investor (Allen \& Faulhaber, 1989; Garanina \& Dumay, 2017). Sinyal tersebut dapat berupa pengungkapan informasi di prospektus

Pengungkapan informasi yang baik pada prospektus akan memberikan nilai tambah bagi perusahaan. Dalam konteks penawaran saham perdana, pengungkapan informasi secara sukarela dapat mengurangi asimetri informasi (Garanina \& Dumay, 2017), sehingga bisa mengurangi underpricing pada saat penawaran saham perdana (Ding, 2016; Widarjo, Rahmawati, Bandi, \& Widagdo, 2017) dan meningkatkan nilai perusahaan (Widarjo, 2011). Hal ini menunjukkan pentingnya pengungkapan informasi kepada investor. Selain itu sinyal tersebut dapat diberikan dalam hal pemilihan underwriter dan auditor (Musteen, Datta, \& Kemmerer, 2010) dan mekanisme corporate governance lainnya. Salah satu mekanisme corporate governance yang penting adalah komisaris independen yang andal. Komisaris independen yang andal akan memberikan nilai tambah bagi perusahaan. Jadi, pada saat penawaran saham perdana sangat penting untuk memiliki komisaris independen yang baik untuk meningkatkan nilai perusahaan.

Penelitian mengenai penawaran saham perdana sudah sangat banyak dilakukan misalnya underpricing pada saat penawaran saham perdana (Hopp \& Dreher, 2013; Rochayani \& Setiawan, 2004) atau kinerja jangka pendek (Sahoo \& Rajib, 2010) dan jangka panjang (Thomadakis, Nounis, \& Gounopoulos, 2012) saat penawaran saham perdana. Selain itu beberapa peneliti mengkaitkan pentingnya pengungkapan informasi saat penawaran saham perdana (Garanina \& Dumay, 2017; Shi, Pukthuanthong, \& Walker, 2013). Akan tetapi penelitian yang terkait dengan pengungkapan informasi secara sukarela saat penawaran saham perdana sangat fokus pada pengungkapan modal intelektual (Garanina \& Dumay, 2017; Pucci, Simoni, \& Zanni, 2015), namun kurang menyentuh aspek pengungkapan yang lain.

Salah satu bentuk pengungkapan yang penting bagi investor adalah pengungkapan risiko (Linsley, Shrives, \& Crumpton, 2006; Solomon, Solomon, Norton, \& Joseph, 2000). Pengungkapan risiko akan memberikan informasi yang berguna saat pengambilan keputusan untuk melakukan investasi. Penelitian sebelumnya menunjukkan pentingnya struktur dewan komisaris terhadap pengungkapan risiko (Ntim, Lindop, \& Thomas, 2013; Probohudono, Tower, \& Rusmin, 2013b). Keberadaan direktur independen di Portugis meningkatkan pengungkapan risiko (Oliveira, Lima Rodrigues, \& Craig, 2011). Akan tetapi penelitian sebelumnya masih sangat jarang yang menguji konteks pengungkapan risiko saat penawaran saham perdana.

Penelitian ini menguji pengungkapan risiko pada saat penawaran saham perdana. Ada beberapa hal yang membedakan penelitian ini dengan penelitian terdahulu. Alasan pertama, penelitian terdahulu mengenai pengungkapan sukarela saat penawaran saham perdana lebih banyak membahas mengenai modal intelektual (Garanina \& Dumay, 2017; Pucci et al., 2015), tetapi jarang yang membahas mengenai pengungkapan risiko. Pengungkapan risiko penting karena membantu investor saat pengambilan keputusan investasi (Solomon et al., 2000). Oleh karena itu, penelitian ini fokus pada pengungkapan risiko saat penawaran saham perdana. Dalam konteks Indonesia, penelitian mengenai pengungkapan saat penawaran saham perdana juga fokus pada modal intelektual (Kusumawardhani, 2012; Widarjo, 2011; Widarjo et al., 2017). Oleh karena itu, penelitian ini akan memberikan sudut pandang yang berbeda mengenai pengungkapan risiko di negeri berkembang. Penelitian yang dilakukan oleh Shi et al. (2013) menunjukkan bahwa sangat penting memahami konteks institusi suatu negara saat melakukan pembahasan mengenai pengungkapan. Hal ini juga merupakan alasan kedua penelitian ini berbeda dengan penelitian terdahulu. Alasan ketiga adalah Indonesia mempunyai konteks institusi yang unik, yaitu perusahaan di Indonesia sebagian besar dikuasai oleh keluarga (Carney \& Child, 2013; Setiawan et al., 2016), sehingga mereka bisa menunjukkan anggota keluarganya di jajaran dewan komisaris. Penelitian ini akan menguji dampak komisaris keluarga terhadap pengungkapan risiko saat penawaran saham perdana. Selain itu, komponen penting lainnya adalah komisaris independen yang andal. Penelitian ini juga akan fokus pada dampak keberadaan komisaris independen terhadap pengungkapan risiko.

Penelitian ini bertujuan untuk memberikan bukti empiris pentingnya keberadaan komisaris keluarga dan komisaris independen terhadap pengungkapan risiko perusahaan Indonesia yang melakukan 
penawaran saham perdana. Selain itu penelitian ini juga menguji enam variabel kontrol yaitu ukuran dewan komisaris, ukuran perusahaan, umur perusahaan, leverage, tingkat profitabilitas (Return on Assets) dan kualitas audit terhadap pengungkapan risiko pada saat penawaran saham perdana.

Penelitian yang dilakukan oleh Wan-Hussin (2009) menunjukkan bahwa keberadaan komisaris yang berasal dari fihak keluarga meningkatkan pengungkapan segmen. Hal ini memberikan bukti anggota keluarga yang menjadi komisaris berpengaruh positif terhadap pengungkapan informasi perusahaan. Hasil ini sejalan dengan Ali, Chen, dan Radhakrishnan (2007) dan Chen, Chen, dan Cheng (2008) yang memberikan bukti bahwa kepemilikan keluarga berpengaruh positif terhadap tingkat pengungkapan. Oleh karena itu penelitian mengajukan hipotesis pertama yaitu keberadaan komisaris keluarga di dewan komisaris memberikan dampak positif terhadap pengungkapan risiko. Komisaris independen mempunyai peran untuk melindungi kepentingan pemegang saham. Salah satu caranya adalah mengurangi asimetri informasi antara manajer dan pemegang saham. Pengurangan asimetri informasi dapat dengan pengungkapan yang lebih detail. Penelitian yang dilakukan oleh Elshandidy, Fraser, dan Hussainey (2013), Ntim, et al. (2013) dan Oliveira, Rodrigues, dan Craig (2011) menunjukkan keberadaan komisaris independen pada memiliki pengaruh positif terhadap level pengungkapan risiko. Investor dapat memperoleh informasi yang lebih banyak mengenai risiko yang dihadapi oleh perusahaan. Oleh karena itu penelitian ini mengajukan hipotesis kedua yaitu komisaris independen berpengaruh positif terhadap pengungkapan risiko.

\section{METODE PENELITIAN}

Penelitian ini merupakan penelitian kuantitatif yang menguji dampak komisaris independen dan komisaris keluarga terhadap pengungkapan risiko pada saat penawaran saham perdana pada periode 2001-2017. Populasi penelitian ini adalah perusahaan yang melakukan penawaran saham perdana di Bursa Efek Indonesia. Sampel penelitian ini adalah perusahaan non-keuangan yang melakukan penawaran saham perdana pada periode 2001-2017. Sumber data penelitian ini adalah laporan prospektus yang diterbitkan oleh perusahaan yang melakukan penawaran saham perdana. Prospektus diperoleh melalui Bursa Efek Indonesia. Pada periode 2001-
2016 terdapat 330 perusahaan yang melakukan penawaran saham perdana. Selanjutnya perusahaan keuangan yang melakukan penawaran saham perdana sebanyak 56 , sedangkan 70 perusahaan lain tidak mempunyai data yang komplit. Sampel akhir dalam penelitian ini adalah 204 perusahaan.

Pengungkapan risiko merupakan variabel dependen yang dianalisis. Variabel independen dalam penelitian ini terdiri dari komisaris keluarga dan komisaris independen. Selanjutnya variabel kontrol terdiri dari enam variabel yaitu ukuran dewan komisaris, ukuran perusahaan, umur perusahaan, leverage, tingkat profitabilitas (Return on Assets) dan kualitas audit. Variabel kontrol ini digunakan karena variabel ini memberikan dampak penting terhadap pengungkapan risiko. Penelitian ini mengukur pengungkapan risiko dengan menggunakan content analysis. Indeks yang digunakan mengacu ke indeks pengungkapan risiko (Risk Disclosure Index/RDI) yang dikembangkan oleh Probohudono et al. (2013a; 2013b; 2013c). Index ini terdiri dari 34 item. Apabila perusahaan mengungkapkan informasi sesuai dengan item yang telah ditetapkan maka akan diberi nilai 1 dan 0 jika tidak mengungkapkan. Nilai maksimal apabila perusahaan mengungkapkan seluruh informasi adalah 34, sesuai dengan jumlah item RDI yang digunakan. Penelitian ini menggunakan rasio untuk mengukur tingkat pengungkapan yaitu jumlah pengungkapan dibagi dengan jumlah maksimal pengungkapan. Komisaris keluarga adalah anggota dewan komisaris yang berasal dari keluarga pemilik perusahaan. Definisi anggota keluarga dalam penelitian ini mengacu ke Prabowo dan Simpson (2011) yang menyatakan anggota keluarga adalah seseorang yang mempunyai hubungan darah melalui pernikahan atau karena pertalian darah seperti ayah, ibu, anak dan kakek. Komisaris keluarga dihitung dengan menggunakan rasio jumlah anggota komisaris yang merupakan anggota keluarga dibagi dengan semua anggota dewan komisaris (Chen, Gray, \& Nowland, 2013; Prabowo \& Simpson, 2011). Pengukuran komisaris independen adalah rasio komisaris independen dibagi dengan jumlah anggota dewan komisaris (Prabowo \& Simpson, 2011).

Ukuran dewan komisaris merupakan jumlah anggota dewan komisaris. Ukuran dewan komisaris yang lebih kecil mempunyai keunggulan dalam hal kecepatan pengambilan keputusan dan kemudahan komunikasi antaranggota (Bliss, 2011; Jensen, 2010). Ukuran perusahaan diukur dengan menggunakan log total asset yang dimiliki oleh perusahaan, sedangkan 
usia perusahaan diukur dengan jumlah tahun semenjak perusahaan tersebut berdiri sampai dengan melakukan penawaran saham perdana. Leverage merupakan rasio antara hutang dibagi dengan ekuitas. Return on Assets merupakan proksi dari rasio profitabilitas, yang diukur dengan membagi laba terhadap asset. Kualitas audit merupakan variabel dummy, yaitu 1 jika perusahaan diaudit oleh KAP yang tergolong Big-4 dan 0 jika diaudit KAP yang tidak tergolong Big-4.

Persamaan yang digunakan untuk penelitian ini adalah sebagai berikut:

$\mathrm{RDI}_{\mathrm{it}}=\alpha+\beta_{1}$ KomKel $+\beta_{2}$ KomInd $+\beta_{3}$ KomUk

$+\beta_{4}$ UkPer $+\beta_{5}$ UsPer $+\beta_{6}$ Lev $+\beta_{7}$ ROA

$+\beta_{8} \mathrm{KA}+\varepsilon$

Keterangan:

$\mathrm{RDI}_{\mathrm{it}}=$ pengungkapan risiko, rasio jumlah pengungkapan/nilai maksimum pengungkapan

KomKel $=$ komisaris keluarga, rasio jumlah komisaris yang berasal dari keluarga pemilik perusahaan/jumlah anggota komisaris

KomInd $=$ komisaris independen, rasio jumlah komisaris independen/jumlah anggota komisaris

KomUk = ukuran dewan komisaris, jumlah anggota dewan komisaris

UkPer = ukuran perusahaan, log total asset

UsPer = usia perusahaan, jumlah tahun antara tahun berdiri perusahaan sampai dengan melakukan penawaran saham perdana

Lev $=$ leverage, rasio hutang/ekuitas

ROA = return on asset, laba dibagi dengan asset

KA $=$ kualitas audit, variabel dummy 1 jika perusahaan diaudit oleh KAP Big-4 dan 0 jika diaudit oleh KAP non Big-4

\section{HASIL DAN PEMBAHASAN}

Tabel 1dan Tabel 2 menyajikan data statistik deskriptif untuk variabel yang digunakan dalam penelitian ini. Tabel 1 menunjukkan nilai tengah pengungkapan risiko pada saat penawaran saham perdana adalah 45,127\%. Nilai ini lebih tinggi dibandingkan deangan data pengungkapan risiko di Indonesia yang ditemukan Probohudono et al.(2013c) yang menunjukkan pengungkapan risiko di perusahaan manufaktur di Indonesia adalah 32\%. Pengungkapan risiko selama proses penawaran saham perdana berkisar antara 26,471\% sampai dengan $64,706 \%$. Selanjutnya komisaris keluarga berkisar antara $0 \%$ sampai dengan $100 \%$, dengan nilai tengah $13,609 \%$. Hal ini menunjukkan keberadaan anggota keluarga di dewan komisaris adalah sebesar 13,609\%. Selanjutnya rata-rata proporsi komisaris independen adalah 34,569\%. Proporsi komisaris independen ini relatif mencukupi dibandingkan peraturan yang mensyaratkan jumlah minimal komisaris independen adalah $30 \%$, sedangkan kisaran keberadaan komisaris independen adalah $0 \%$ sampai dengan $66,67 \%$.

Tabel 1. Statistik Deskriptif

\begin{tabular}{lrrrr}
\hline \multicolumn{1}{c}{ Variabel } & \multicolumn{1}{c}{ Minimal } & \multicolumn{1}{c}{ Maximal } & \multicolumn{1}{c}{ Mean } & Standard Deviasi \\
\hline RDI & 26,471 & 64,706 & 45,127 & 8,571 \\
KomKel & 0,000 & 66,667 & 14,855 & 17,908 \\
KomInd & 0,000 & 66,667 & 34,659 & 13,303 \\
KomUk & 2,000 & 22,000 & 3,670 & 1,948 \\
UkPer & 23,393 & 30,679 & 27,341 & 1,473 \\
UsPer & 2,000 & 144,000 & 17,675 & 15,637 \\
Lev & 0,031 & 12,259 & 1,975 & 1,811 \\
ROA & $-1,238$ & 0,506 & 0,055 & 0,124 \\
N & 204,000 & & & \\
\hline
\end{tabular}

$\mathrm{RDI}_{\mathrm{it}}=$ pengungkapan risiko, rasio jumlah pengungkapan/nilai maksimum pengungkapan, KomKel = komisaris keluarga, rasio jumlah komisaris yang berasal dari keluarga pemilik perusahaan/jumlah anggota komisaris, KomInd= komisaris independen, rasio jumlah komisaris independen/jumlah anggota komisaris, KomUk = ukuran dewan komisaris, jumlah anggota dewan komisaris, UkPer $=$ ukuran perusahaan, log total asset, UsPer $=$ usia perusahaan, jumlah tahun antara tahun berdiri perusahaan sampai 
dengan melakukan penawaran saham perdana, Lev

asset, laba dibagi dengan asset

$=$ leverage, rasio hutang/ekuitas, $\mathrm{ROA}=$ return on

Tabel 2. Statistik Deskriptif untuk Variabel Dummy

\begin{tabular}{lccc}
\hline & Variabel & Frekuensi 1 & Frekuensi 0 \\
\hline KA & 204 & 0,271 & 0,729 \\
$\mathrm{~N}$ & & \\
\hline KA & $=$ kualitas audit, variabel dummy & 1 jika perusahaan diaudit oleh KAP Big-4 dan 0 jika diaudit oleh \\
KAP non Big-4 &
\end{tabular}

Ukuran dewan komisaris berkisar antara 2 orang sampai dengan 22 orang, dengan nilai rata-rata sebesar 4 orang untuk anggota dewan komisaris. Usia perusahaan berkisar antara 2 tahun sebagai perusahaan termuda sampai dengan 144 tahun sebagai perusahaan tertua. Rata-rata umur perusahaan adalah 17,672 tahun. Rasio leverage dalam penelitian ini berkisar antara 3,1\% sampai dengan $1225 \%$. Rata-rata leverage adalah $181,13 \%$. Data ini menunjukkan struktur modal perusahaan didominasi oleh hutang daripada modal sendiri. Tabel 2 menunjukkan data statistik deskriptif untuk variabel kualitas audit. Sebagian besar perusahaan yang melakukan penawaran saham perdana diaudit oleh KAP non-Big 4, yaitu sebanyak $72,9 \%$ perusahaan yang diaudit non-Big 4. Persentase perusahaan yang diaudit oleh KAP Big-4 adalah sebanyak 27,1\%.

Tabel 3 berikut ini menyajikan hasil pengujian hipotesis. Tabel 3 menunjukkan komisaris keluarga berpengaruh positif terhadap pengungkapan risiko perusahaan pada saat perusahaan melakukan penawaran saham perdana. Hal ini menunjukkan keberadaan komisaris yang berasal dari keluarga pemilik berdampak positif terhadap luas pengungkapan risiko. Komisaris keluarga menekankan pentingnya informasi mengenai risiko yang dihadapi oleh perusahaan untuk disampaikan kepada investor. Dalam konteks ini komisaris keluarga menyampaikan sinyal kepada investor mengenai informasi tentang risiko. Sinyal yang diberikan ini diharapkan mampu mengurangi kesenjangan informasi antara perusahaan dan investor (Ding, 2016; Garanina \& Dumay, 2017; Widarjo et al., 2017). Dengan mempunyai informasi yang lebih lengkap maka diharapkan investor dapat mengambil keputusan investasi yang tepat. Selain itu, usaha komisaris keluarga untuk mengungkapkan risiko mengenai perusahaan dengan lebih lengkap menunjukkan kesediaan fihak pemilik untuk berbagi informasi. Hal ini merupakan sinyal positif bagi investor, sehingga diharapkan investor bersedia untuk menanamkan modalnya kepada perusahaan.

Tabel 3 . Hasil Pengujian Statistik

\begin{tabular}{|c|c|c|c|}
\hline Variabel & $\beta$ & $t_{\text {hitung }}$ & probabilitas \\
\hline A & $-26,107$ & $-2,392$ & $0,009^{\mathrm{a}}$ \\
\hline KomKel & 0,055 & 1,844 & $0,033^{\mathrm{b}}$ \\
\hline KomInd & 0,121 & 2,823 & $0,002^{\mathrm{a}}$ \\
\hline KomUk & $-0,058$ & $-0,202$ & 0,420 \\
\hline UkPer & 2,404 & 5,551 & $0,000^{\mathrm{a}}$ \\
\hline UsPer & 0,023 & 0,667 & 0,253 \\
\hline Lev & 0,139 & 0,447 & 0,328 \\
\hline ROA & 0,175 & 0,040 & 0,484 \\
\hline KA & 0,499 & 0,407 & 0,342 \\
\hline $\mathrm{N}$ & 203 & & \\
\hline $\operatorname{Adj}^{2}$ & 0,242 & & \\
\hline $\mathrm{FS}_{\text {tat }}$ & $9,07^{\mathrm{a}}$ & & \\
\hline
\end{tabular}

a,b signifikan pada $1 \%, 5 \%$.

$\mathrm{RDI}_{\mathrm{it}}=$ pengungkapan risiko, rasio jumlah pengungkapan/nilai maksimum pengungkapan, KomKel $=$ komisaris keluarga, rasio jumlah komisaris yang berasal dari keluarga pemilik perusahaan/ jumlah anggota komisaris, KomInd= komisaris independen, rasio jumlah komisaris independen/ 
jumlah anggota komisaris, KomUk = ukuran dewan komisaris, jumlah anggota dewan komisaris, UkPer= ukuran perusahaan, log total asset, UsPer $=$ usia perusahaan, jumlah tahun antara tahun berdiri perusahaan sampai dengan melakukan penawaran saham perdana, Lev = leverage, rasio hutang/ekuitas, $\mathrm{ROA}=$ return on asset, laba dibagi dengan asset $\mathrm{KA}=$ kualitas audit, variabel dummy 1 jika perusahaan diaudit oleh KAP Big-4 dan 0 jika diaudit oleh KAP non Big-4

Hasil penelitian ini menunjukkan komisaris keluarga tidak hanya sekedar memperjuangkan kepentingan keluarga saja, tetapi juga memberikan ruang bagi investor lain untuk memperoleh informasi yang lebih lengkap. Komisaris keluarga tidak hanya mementingkan kepentingan sendiri saja, tetapi kepentingan yang lebih luas. Hasil ini sesuai dengan teori stewardship yang menyatakan bahwa komisaris mementingkan kepentingan bersama daripada kepentingan diri sendiri (Davis, Schoorman, \& Donaldson, 1997). Hasil ini sejalan dengan penelitian Chen, Chen dan Cheng (2008) yang menunjukkan bahwa perusahaan yang dikuasai keluarga akan memberikan lebih banyak peringatan mengenai pencapaian laba. Perusahaan keluarga memberikan informasi mengenai risiko yang dihadapi oleh investor terkait dengan usaha perusahaan dalam memperoleh laba di masa depan. Ali et al. (2007) juga menunjukkan bahwa perusahaan yang dikuasai oleh keluarga memberikan pengungkapan sukarela yang lebih luas dibandingkan dengan perusahaan nonkeluarga. Hasil penelitian Ali et al.(2007) dan Shuping Chen et al. (2008) menunjukkan bahwa perusahaan keluarga peduli terhadap pemilik saham minoritas, sehingga mereka memberikan informasi yang lebih lengkap. Penelitian yang dilakukan oleh Yoshikawa dan Rasheed (2010) membuktikan keberadaan direktur yang berasal dari keluarga memberikan pengaruh positif terhadap kebijakan perusahaan dalam memberikan dividen. Jadi keberadaan direktur yang berasal dari keluarga mampu memberikan return investasi yang lebih besar bagi investor. WanHussin (2009) dalam penelitiannya dengan menggunakan sampel perusahaan di Malaysia menunjukkan bahwa keberadaan direktur yang berafiliasi dengan pemilik perusahaan memberikan dampak positif terhadap pengungkapan segmen di laporan keuangan. Hasil penelitian ini mengkonfirmasi dampak positif keberadaan komisaris keluarga dalam hal pengungkapan risiko.

Tabel 3 juga menunjukkan bahwa komisaris independen berpengaruh positif terhadap pengungkapan risiko pada perusahaan yang melakukan penawaran saham perdana. Keberadaan komisaris independen mampu mendorong perusahaan untuk mengungkapkan lebih banyak informasi mengenai risiko kepada investor. Komisaris independen mampu mengemban tugasnya dengan baik untuk melindungi kepentingan semua pemegang saham. Informasi mengenai risiko yang ditampilkan kepada publik diharapkan mampu memberikan sudut pandang yang lebih luas bagi investor untuk mengambil keputusan, sehingga investor mampu mengambil keputusan yang lebih baik (Solomon et al., 2000). Pemilihan komisaris independenyang andal merupakan salah satu bentuk sinyal yang diberikan oleh perusahaan kepada investor, bahwa perusahaan akan memperhatikan kepentingan semua fihak.

Penelitian ini mengkonfirmasi peran penting komisaris independen dalam hal pengungkapan risiko. Komisaris independen memberikan pengaruh positif terhadap luas pengungkapan risiko pada saat perusahaan melakukan penawaran saham perdana di Indonesia. Penelitian yang dilakukan oleh Oliveira, et al. (2011) menunjukkan keberadaan komisaris independen pada perusahaan Portugal yang terdaftar di Bursa Efek memiliki pengaruh positif terhadap level pengungkapan risiko. Investor di Portugal dapat memperoleh informasi yang lebih banyak mengenai risiko yang dihadapi oleh perusahaan. Hal ini juga sejalan dengan penelitian Elshandidy et al. (2013) yang menunjukkan keberadaan komisaris independen di Inggris juga berdampak positif terhadap pengungkapan risiko yang dihadapi oleh perusahaan. Hasil yang seragam juga ditemukan oleh Ntim et al. (2013) yang menunjukkan komisaris independen di Afrika Selatan berpengaruh positif terhadap pengungkapan risiko yang dihadapi oleh perusahaan. Oleh karena itu, penelitian ini sejalan dengan Elshandidy et al. (2013), Ntim et al. (2013) dan Oliveira et al. (2011) yang menunjukkan pengaruh positif komisaris independen terhadap luas pengungkapan risiko yang dihadapi oleh perusahaan. Akan tetapi penelitian ini tidak sejalan dengan Suhardjanto dan Dewi (2011) yang menunjukkan komisaris independen di Indonesia tidak berpengaruh terhadap pengungkapan risiko pada perusahaan perbankan di Indonesia. Penelitian yang dilakukan oleh Prabowon dan Simpson (2011) juga menunjukkan bahwa komisaris independen di Indonesia tidak berperan efektif dalam membantu perusahaan mencapai kinerja yang lebih baik. 
Tabel 3 juga menunjukkan dampak variabel kontrol terhadap pengungkapan risiko perusahaan yang melakukan penawaran saham perdana. Hasil penelitian menunjukkan bahwa variabel ukuran perusahaan berpengaruh positif terhadap pengungkapan risiko. Perusahaan besar cenderung mengungkapan informasi mengenai risiko lebih lengkap dibandingkan perusahaan kecil. Perusahaan besar memperoleh sorotan yang lebih banyak dari fihak regulator dan masyarakat, sehingga perusahaan cenderung untuk memberikan pengungkapan risiko yanglebih luas (Probohudono et al., 2013b, 2013c). Akan tetapi variabel lainnya seperti ukuran dewan komisaris tidak berpengaruh terhadap luas pengungkapan. Hasil ini menunjukkan jumlah anggota dewan komisaris tidak mempengaruhi keputusan perusahaan untuk mengungkapkan risiko. Selain itu leverage, ROA, usia perusahaan dan kualitas audit tidak mempengaruhi kebijakan perusahaan dalam hal pengungkapan risiko.

\section{SIMPULAN}

Penelitian ini menguji keberadaan komisaris keluarga dan komisaris independen terhadap pengungkapan risiko pada saat perusahaan melakukan penawaran saham perdana. Penelitian ini membuktikan keberadaan komisaris keluarga berpengaruh positif terhadap pengungkapan risiko. Komisaris keluarga berperan penting untuk mendorong perusahaan mengungkapkan lebih banyak informasi mengenai risiko yang dihadapi perusahaan di prospectus yang dikeluarkan perusahaan. Hasil ini juga menunjukkan bahwa komisaris keluarga tidak hanya mementingkan kepentingan keluarga pemilik perusahaan saja, tetapi juga memperhitungkan kepentingan yang lebih luas yaitu kepentingan seluruh pemegang saham. Informasi yang lebih luas mengenai risiko yang dihadapi oleh perusahaan akan membantu perusahaan dalam mengambil keputusan investasi.

Komisaris independen mempunyai pengaruh positif terhadap pengungkapan risiko. Komisaris independen menjalankan tugasnya dengan efektif. Komisaris independen mampu menggerakkan perusahaan untuk mengungkapkan informasi mengenai risiko yang lebih luas di prospectus. Hasil ini juga mengkonfirmasi dugaan peran penting komisaris independen sebagai salah satu komponen penting di corporate governance. Keberadaan komisaris independen dapat memberikan nilai tambah pada informasi risiko yang diungkapkan.
Implikasi praktis penelitian ini adalah menunjukkan pentingnya peran komisaris keluarga dan komisaris independen pada saat penawaran saham perdana. Keberadaan komisaris independen dan komisaris keluarga mampu meningkatkan luas pengungkapan risiko yang dihadapi oleh perusahaan. Oleh karena itu, perusahaan yang akan melakukan penawaran saham perdana diharapkan mempertahankan keberadaan anggota keluarga di dewan komisaris untuk menunjukkan kemauan perusahaan dalam berbagi informasi kepada pemegang saham lainnya. Selain itu, perusahaan juga harus memastikan keberadaan komisaris independen di dalam dewan komisaris yang menunjukkan sinyal bahwa perusahaan juga melindungi kepentingan semua pemegang saham. Fungsi komisaris independen adalah memperjuangkan kepentingan semua pemegang saham, misalnya memberikan informasi yang lebih luas mengenai risiko yang dihadapi oleh perusahaan.

Komisaris keluarga dan komisaris independen mempunyai peran penting untuk mendorong perusahaan memberikan pengungkapan yang lebih luas mengenai risiko yang dihadapi. Penelitian selanjutnya bisa mengeksplorasi karakteristik dewan komisaris lainnya, misal keberadaan komisaris wanita di dalam dewan komisaris. Apakah komisaris memberikan nilai tambah bagi pengungkapan risiko oleh perusahaan pada saat penawaran saham perdana? Selain itu, penelitian selanjutnya bisa mengeksplorasi karakteristik anggota dewan komisaris seperti umur, latar belakang pendidikan dan lama masa jabatan. Teori upper echelon menyatakan karakteristik ini berpengaruh dalam membantu dewan komisaris untuk menjalankan tugasnya. Oleh karena itu, penelitian selanjutnya bisa menguji dampak karakteristik individu anggota dewan komisaris terhadap pengungkapan risiko.

\section{REFERENSI}

Ali, A., Chen, T.-Y., \& Radhakrishnan, S. (2007). Corporate disclosures by family firms. Journal of Accounting and Economics, 44(1), 238-286.

Allen, F., \& Faulhaber, G. R. (1989). Signalling by underpricing in the IPO market. Journal of Financial Economics, 23(2), 303-323.

Bliss, M. A. (2011). Does CEO duality constrain board independence? Some evidence from audit pricing. Accounting \& Finance, 51(2), 361 - 380.

Carney, R. W., \& Child, T. B. (2013). Changes to the ownership and control of East Asian 
corporations between 1996 and 2008: The primacy of politics. Journal of financial economics, 107(2), 494-513.

Chen, E. T., Gray, S., \& Nowland, J. (2013). Family representatives in family firms. Corporate Governance: An International Review, 21(3), $242-263$.

Chen, S., Chen, X., \& Cheng, Q. (2008). Do Family Firms Provide More or Less Voluntary Disclosure? Journal of Accounting Research, 46(3), 499-536. doi:10.1111/j.1475-679X.2008. 00288.x

Chen, S., Chen, X., \& Cheng, Q. (2008). Do family firms provide more or less voluntary disclosure? Journal of Accounting Research, 46(3), 499 - 536.

Davis, J. H., Schoorman, F. D., \& Donaldson, L. (1997). Toward a Stewardship Theory of Management. The Academy of Management Review, 22(1), 20-47. doi:10.2307/259223

Ding, R. (2016). Disclosure of Downside Risk and Investors' Use of Qualitative Information: Evidence from the IPO Prospectus's Risk Factor Section. International Review of Finance, 16(1), 73-126. doi:10.1111/irfi.12066

Elshandidy, T., Fraser, I., \& Hussainey, K. (2013). Aggregated, voluntary, and mandatory risk disclosure incentives: Evidence from UK FTSE all-share companies. International Review of Financial Analysis, 30, 320-333. doi:https:// doi.org/10.1016/j.irfa.2013.07.010

Garanina, T., \& Dumay, J. (2017). Forward-looking intellectual capital disclosure in IPOs: Implications for intellectual capital and integrated reporting. Journal of Intellectual Capital, 18(1), 128-148. doi:10.1108/JIC-05-2016-0054

Hopp, C., \& Dreher, A. (2013). Do differences in institutional and legal environments explain crosscountry variations in IPO underpricing? Applied Economics, 45(4), 435-454.

Jensen, M. C. (2010). The modern industrial revolution, exit, and the failure of internal control systems. Journal of applied corporate finance, 22(1), 43-58.

Kusumawardhani, T. (2012). Intellectual Capital, Financial Profitability, and Productivity: An Exploratory Study of the Indonesian Pharmaceutical Industry. Asian Journal of Business and Accounting, 5(2).

Linsley, P. M., Shrives, P. J., \& Crumpton, M. (2006). Risk disclosure: An exploratory study of UK and
Canadian banks. Journal of Banking Regulation, 7(3-4), 268-282.

Musteen, M., Datta, D. K., \& Kemmerer, B. (2010). Corporate Reputation: Do Board Characteristics Matter? British Journal of Management, 21(2),498-510. doi:10.1111/j.1467-8551.2009.00676.x

Ntim, C. G., Lindop, S., \& Thomas, D. A. (2013). Corporate governance and risk reporting in South Africa: A study of corporate risk disclosures in the pre- and post-2007/2008 global financial crisis periods. International Review of Financial Analysis, 30, 363-383. doi:https:/ /doi.org/10.1016/j.irfa.2013.07.001

Oliveira, J., Lima Rodrigues, L., \& Craig, R. (2011). Risk related disclosures by non finance companies: Portuguese practices and disclosure characteristics. Managerial Auditing Journal, 26(9), 817-839. doi:10.1108/02686901111171466

Prabowo, M. A., \& Simpson, J. (2011). Independent directors and firm performance in family controlled firms: Evidence from Indonesia. Asian-Pacific Economic Literature, 25(1), 121-132.

Probohudono, A. N., Tower, G., \& Rusmin, R. (2013a). Diversity in risk communication. Australasian Accounting, Business and Finance Journal, 7(1), 43-58.

Probohudono, A. N., Tower, G., \& Rusmin, R. (2013b). Risk disclosure during the global financial crisis. Social Responsibility Journal, 9(1), 124-137.

Probohudono, A. N., Tower, G., \& Rusmin, R. (2013c). A risky tale of two countries. Asian Review of Accounting, 21(3), 257-272.

Pucci, T., Simoni, C., \& Zanni, L. (2015). Measuring the relationship between marketing assets, intellectual capital and firm performance. Journal of Management \& Governance, 19(3), 589-616. doi:10.1007/s10997-0139278-1

Rochayani, W., \& Setiawan, D. (2004). Pengaruh Informasi Prospektus IPO Terhadap Abnormal Returns Dan Ketepatan Ramalan Laba. Jurnal EKonomi Perusahaan, 11(2), 107 - 124.

Sahoo, S., \& Rajib, P. (2010). After Market Pricing Performance of Initial Public Offerings (IPOs): Indian IPO Market 2002-2006. Vikalpa, 35(4), 27-44. doi:10.1177/0256090920100403

Setiawan, D., Bandi, B., Phua, L. K., \& Trinugroho, I. (2016). Ownership structure and dividend policy in Indonesia. Journal of Asia Business Studies, 10(3), 230 - 252. 
Shi, C., Pukthuanthong, K., \& Walker, T. (2013). Does Disclosure Regulation Work? Evidence from International IPO Markets. Contemporary Accounting Research, 30(1), 356387.doi:10.1111/j.1911-3846.2012.01158.x

Solomon, J. F., Solomon, A., Norton, S. D., \& Joseph, N. L. (2000). A conceptual framework for corporate risk disclosure emerging from the agenda for corporate governance reform. The British Accounting Review, 32(4), 447-478. doi:http://dx.doi.org/10.1006/bare.2000.0145

Suhardjanto, D., \& Dewi, A. (2011). Pengungkapan risiko finansial dan tata kelola perusahaan: Studi empiris perbankan Indonesia. Jurnal Keuangan dan Perbankan, 15(1), 105-118.

Thomadakis, S., Nounis, C., \& Gounopoulos, D. (2012). Long term Performance of Greek IPOs. European Financial Management, 18(1), 117-141.

Wan-Hussin, W. N. (2009). The impact of familyfirm structure and board composition on corporate transparency: Evidence based on segment disclosures in Malaysia. The International Journal of Accounting, 44(4), 313-333. doi:https://doi.org/10.1016/ j.intacc.2009.09.003

Widarjo, W. (2011). Pengaruh Modal Intelektual dan Pengungkapan Modal Intelektual pada Nilai Perusahaan yang melakukan Initial Public Offering. Jurnal Akuntansi dan Keuangan Indonesia, 8(2), 157 - 170.

Widarjo, W., Rahmawati, Bandi, \& Widagdo, A. K. (2017). Underwriter Reputation, Intellectual Capital Disclosure, and Underpricing. International Journal of Business and Society, 18(2), 227-244.

Yoshikawa, T., \& Rasheed, A. A. (2010). Family control and ownership monitoring in familycontrolled firms in Japan. Journal of Management studies, 47(2), 274-295. doi:10.1111/j.1467-6486.2009.00891.x 